\title{
Interpretacja jakościowa i ilościowa przestrzeni porowej piaskowca karbońskiego na podstawie wyników rentgenowskiej tomografii komputerowej
}

\begin{abstract}
W pracy przedstawiono analizę przestrzeni porowej dwóch próbek karbońskich piaskowców kwarcowych z wykorzystaniem rentgenowskiej tomografii komputerowej (CT). Pierwszy etap prac stanowiło przetwarzanie obrazów CT. Przetwarzanie miało na celu poprawę stosunku sygnału do szumu oraz podniesienie rozpiętości tonalnej obrazów. Kolejnym etapem było stworzenie obrazu zbinaryzowanego. Następnie na podstawie przekrojów 2D i obrazu 3D dokonano interpretacji jakościowej i ilościowej przestrzeni porowej. Interpretacja jakościowa polegała na porównaniu uzyskanych podgrup sieci porowej między sobą, jak też między próbkami. Wyliczono porowatość całkowitą oraz zmiany porowatości w kolejnych przekrojach CT. Dane posłużyły również do analizy pola powierzchni porów oraz do policzenia charakterystyki Eulera. Obiekt charakteryzujący się największą objętością został użyty do obliczenia porowatości efektywnej, długości sieci porowej, liczby gałęzi i skrzyżowań, krętości kanału porowego. Uzyskana porowatość całkowita była zbliżona do obliczonej z wykorzystaniem innych metod laboratoryjnych. Policzono też liczbę porów przypadającą na każdy przekrój oraz średni rozmiar porów na przekrój CT. Dokonano podziału przestrzeni porowej próbek na klasy powierzchni, obliczono liczbę porów przyporządkowanych do danej klasy oraz ich procentowy udział w budowaniu całej przestrzeni porowej. Dla sieci porów odizolowanych dokonano podziału na klasy objętości, następnie stwierdzono liczbę elementów w danej klasie oraz jej procentowy udział. Próbka nr 1 wykazała heterogeniczność w wykształceniu przestrzeni porowej, cechowała się większą liczbą porów, lepszą jakością połączeń struktury porowej oraz miała więcej porów o mniejszych objętościach. Średni rozmiar porów próbki nr 2 był większy. Przestrzeń porową próbki nr 2 tworzyły pory o większej powierzchni. Obliczona krętość kanału porowego wynosiła 2,17. Micro-CT okazało się dobrym narzędziem do szczegółowej analizy budowy przestrzeni porowej skał.
\end{abstract}

Słowa kluczowe: petrofizyka, rentgenowska mikrotomografia komputerowa, przestrzeń porowa, krętość kanałów porowych, porowatość całkowita, porowatość efektywna.

\section{Qualitative and quantitative interpretation of Carboniferous sandstone pore space on the basis of X-ray computed tomography results}

The paper presents an analysis of the pore space of two Carboniferous quartz sandstone samples using X-ray computed tomography $(\mathrm{CT})$. The first stage of the work was the processing of CT images. The processing was aimed at improving the signal-to-noise ratio and increasing the tonal range of images. The next stage was to create a binary image. Next, a qualitative and quantitative interpretation of the pore space was made on the basis of $2 \mathrm{D}$ sections and $3 \mathrm{D}$ images. The qualitative interpretation consisted in comparing the obtained pore network subgroups with each other and between samples. The total porosity and changes in porosity in subsequent $\mathrm{CT}$ cross-sections were calculated. The data also served to analyze the pore surface area and to calculate the Euler's characteristics. The object with the largest volume was used to calculate the effective porosity, the length of the pore network, the number of branches and intersections, and the tortuosity of the pore channel. The obtained total porosity was similar to that calculated using other laboratory methods. The number of pores per each cross-section and the average pore size per CT section were also counted. The pore space of samples was divided into surface classes. The number of pores assigned to a given class was calculated as well as their percentage share in building the entire pore space. For the network of isolated pores, the division into volume classes was made, then the number of elements in a given class and its percentage share were counted. Sample no. 1 showed heterogeneity in the development of pore space, was characterized by more pores, better quality of pore structure connections and had more pores with smaller volumes. 
The average pore size of sample no. 2 was larger. The pore space of sample no. 2 was made up of pores with a larger surface area. The calculated tortuosity of the pore channel was 2.17. Micro-CT proved to be a good tool for a detailed analysis of the structure of the rocks pore space.

Key words: petrophysics, computed microtomography, pore space, tortuosity, total porosity, effective porosity.

\section{Wprowadzenie}

Wyniki rentgenowskiej tomografii komputerowej w obecnych czasach stały się narzędziem do interpretacji jakościowej i ilościowej przestrzeni porowej skał [1,13]. Rentgenowska tomografia komputerowa (CT) pozwala na uzyskanie obrazów 2D i 3D, w których elementom o różnych gęstościach w skale przyporządkowane są piksele o różnym stopniu zaciemnienia $[2,9]$. Jasne obszary odpowiadają za wysoką gęstość elementu (obiektu) w skale (np. piryty), a ciemne obszary - za niską gęstość obiektu (np. przestrzeń porowa wypełniona medium: wodą lub węglowodorami) [4].

Dużą zaletą metody jest możliwość bezpośredniej obserwacji przestrzeni porowej, co pozwala na określenie jej struktury i zaobserwowanie występujących niejednorodności. Dzięki interpretacji ilościowej obrazów tomograficznych skał możliwe jest wyliczanie liczbowych charakterystyk przestrzeni porowej, takich jak:
- współczynnik porowatości całkowitej - stosunek objętości porów w próbce skały do całkowitej objętości danej próbki skały [7];

- współczynnik porowatości efektywnej - stosunek objętości porów komunikujących się ze sobą do całkowitej objętości próbki skały [7];

- krętość kanałów porowych - stosunek długości ścieżki między dwoma punktami i odległości euklidesowej między nimi. Parametr ten charakteryzuje strukturę porów i zależy od rozmiaru ziaren i stopnia ich niejednorodności [8];

- charakterystyka Eulera - różnica między liczbą izolowanych porów i liczbą połączeń między porami w próbce. Dobrze połączona sieć porów przyjmuje wartości ujemne, a słabo połączona - dodatnie [3].

\section{Materiał i przygotowanie danych}

Pomiary rentgenowskiej tomografii komputerowej zostały wykonane przez Instytut Nafty i Gazu w Krakowie, w Zakładzie Geofizyki Wiertniczej, przy zastosowaniu mikrotomografu rentgenowskiego Benchtop CT160, ze źródłem rentgenowskim emitującym stożkową wiązkę fotonów o energii z zakresu $40 \div 160 \mathrm{kV}$ i rozdzielczości dochodzącej do $3 \mu \mathrm{m}$. Taka rozdzielczość pozwalała na analizę porów o średnicy mniejszej niż $0,1 \mathrm{~mm}$.

Materiałami poddanymi badaniom były następujące próbki piaskowców karbońskich:

- próbka nr 1 - piaskowiec kwarcowy piętra wizenu uzyskany z głębokości 3008 m, z wiercenia na obszarze synklinorium pomorskiego, należący do formacji piaskowców kwarcowych z Drzewian,

- próbka nr 2 - piaskowiec kwarcowy z piętra turneju górnego uzyskany z głębokości 3154 m, z wiercenia na obszarze antyklinorium pomorskiego.

Rentgenowską tomografię komputerową dla próbek wykonano $\mathrm{z}$ rozdzielczością 5,6 $\mu \mathrm{m}$.

Przed rozpoczęciem właściwej interpretacji należało wywołać i wykadrować dane, które zostały udostępnione w formacie VOL. Następnie przystąpiono do przetwarzania obrazów tomograficznych mającego na celu poprawę stosunku sygnału do szumu oraz podniesienie rozpiętości tonalnej, któ- rą definiujemy jako różnice pomiędzy najjaśniejszymi i najciemniejszymi punktami obrazu. Różnice te opisywane są przez parametr zwany stopniami zaczernienia. Przyjmuje on wartość 0 dla najciemniejszych wokseli, a 255 dla najjaśniejszych. Kolejnym etapem było stworzenie obrazu zbinaryzowanego (składającego się tylko z czarnych i białych pikseli) dla obu próbek. Uzyskany w ten sposób obraz uznano za dane wejściowe do dalszej interpretacji w programie ImageJ.

$\mathrm{Z}$ danych wejściowych wydzielono obiekt o największej objętości. Sieć porów połączonych najczęściej stanowi obiekt o największej objętości. Pozostałe obiekty uznano za pory odseparowane. Zostały one wyliczone poprzez odjęcie obiektu o największej objętości od danych wejściowych. W ten sposób uzyskano trzy pliki odpowiadające różnym konfiguracjom przestrzeni porowej: plik z porowatością całkowitą (pory połączone i odseparowane), z porowatością efektywną (tylko sieć porów połączonych) oraz tylko z porami zamkniętymi.

Interpretacja jakościowa polegała na porównaniu uzyskanych plików (podgrup sieci porowej) między sobą, jak też między próbkami. Wykorzystano do tego celu przekroje 2D oraz wizualizacje 3D. W interpretacji ilościowej dane wejściowe zostały wykorzystane do wyliczenia porowatości całkowitej oraz zmian porowatości w kolejnych przekrojach tomograficznych. Posłużyły one również do analizy pola powierzchni porów 
i do policzenia charakterystyki Eulera. Obiekt o największej objętości został użyty do obliczenia porowatości efektywnej, długości sieci porowej, liczby gałęzi i skrzyżowań oraz do policzenia krętości kanałów porowych.

\section{Przetwarzanie obrazów tomograficznych}

Przed przystąpieniem do interpretacji jakościowej i ilościowej danych tomograficznych należało poddać je procesowi przetwarzania. Negatywne efekty, takie jak zaszumienie, niska rozpiętość tonalna, słaba ostrość obrazu itd., mogłyby prowadzić do niepoprawnego określenia parametrów wchodzących w skład interpretacji jakościowej. Priorytetem w przetwarzaniu było uzyskanie jak najbardziej wiernego odzwierciedlenia rzeczywistego ośrodka skalnego, takiego, aby ciemniejsze woksele - odpowiadające za przestrzeń porową skały były ostro odgraniczone od reszty obrazu. Przetwarzanie obrazów wykonywano przy użyciu programów Adobe Photoshop CC 2015 i ImageJ.

Pierwszym krokiem było zastosowanie procedur odszumiania. Jako że uzyskane zdjęcia są czarno-białe, posiadają one tylko szum luminancji, czyli są to przypadkowe zmiany wartości zaczernienia pikseli/wokseli. Może to prowadzić do błędnego obliczenia porowatości. Taki rodzaj szumu jest trudny do usunięcia i trzeba umiejętnie dostosować moc filtra. Zbyt silne odszumienie prowadzi do pogorszenia ostrości obrazu, a następnie do obliczenia zaniżonej wartości porowatości. Natomiast zbyt słabe odszumienie może doprowadzić do zawyżenia wartości porowatości. Zdecydowano się na odszumienie przy użyciu procedury „Detail - Noise reduction”, z wykorzystaniem modułu Adobe Bridge (wchodzącego w skład pakietu Photoshop) z parametrami: stopnia filtra $25 \%$ i promieniem wynoszącym 1 piksel. Połączono je później z łagodną filtracją Gaussa $3 \mathrm{D}$ w programie ImageJ. W ten sposób pozbyto się negatywnego wpływu szumu na porowatość. Dla obu próbek szum ten podnosił wartość porowatości całkowitej o około $2 \%$.

Kolejnym etapem przetwarzania było zastosowanie polecenia „Curves” w programie Photoshop. Polega ono na lokalnej zmianie kontrastu obrazu. W ten sposób można zwiększyć rozpiętość tonalną ciemnych obszarów, na których będzie głównie zależeć w etapie binaryzacji. Celem tego etapu było sprawienie, aby ciemne piksele, odpowiadające za przestrzeń porową, jak najbardziej wyróżniały się z otoczenia.
Ostatnim etapem przetwarzania jest binaryzacja, zwana także progowaniem. Polega ona na stworzeniu mapy bitowej $[0,1]$ składającej się tylko z zer - czarnych pikseli oraz jedynek - białych pikseli, odpowiadających za przestrzeń porową. W tym przypadku dochodzi do odwrócenia sytuacji: przed binaryzacją pory były czarne. Zastosowano binaryzację za pomocą progowania. Polega ona na wyborze poziomu zaczernienia pikseli, dla którego wszystkie piksele mniejsze od zadanej wartości zostaną uznane za przestrzeń porową. Efekt tej procedury został zobrazowany na rysunku 1.

Odpowiednie dobranie parametru progowania jest istotne, gdyż nawet małe jego zmiany, np. o 5 wartości zaczernienia pikseli, mogą prowadzić do wzrostu porowatości nawet o $10 \%$. Wszystkie poprzednie kroki przetwarzania miały pomóc w poprawnym doborze progu.

Należy mieć na uwadze, że proces binaryzacji jest destrukcyjny i powoduje utratę znaczącej ilości danych, dlatego powinien on zawsze być ostatnim etapem przetwarzania. Dla każdej próbki kryteria doboru parametrów binaryzacji są inne - mogą się nieznacznie różnić, jednak muszą podlegać kontroli interpretatora. Binaryzacja jest jednak konieczna do celów interpretacji jakościowej i ilościowej. Większość dostępnych procedur interpretacyjnych wymaga zbinaryzowanego obrazu jako pliku wejściowego.

Odpowiednio dobierając progi binaryzacji, można wydzielić minerały o zadanej gęstości.

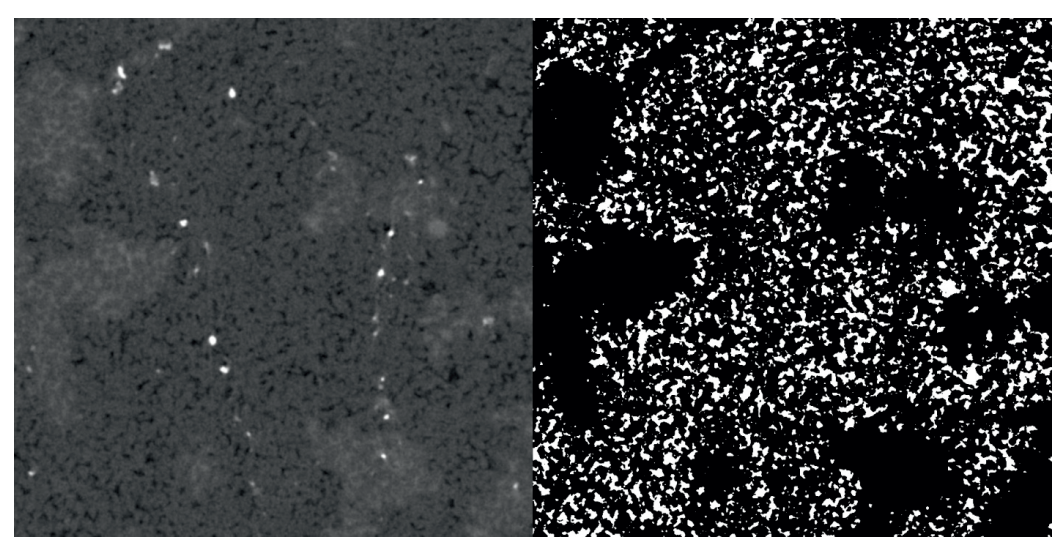

Rys. 1. Porównanie obrazu w próbce nr 1 przed (lewa strona) i po procesie binaryzacji (prawa strona)

\section{Interpretacja jakościowa}

Interpretacja jakościowa została przeprowadzona na podstawie wizualizacji 3D przestrzeni porowej dla obu próbek w programie ImageJ, przy użyciu modułu 3D Viewer [11]. Na podstawie zwizualizowanych w 3D danych tomograficznych stwierdzono, że próbka nr 1 ma bardziej nieregularną sieć porową niż próbka nr 2 . W próbce nr 1 licznie występują puste 
obszary, które zostały zaznaczone na czerwono na rysunku 2. Przedstawiają one lokalizację dużych ziaren mineralnych.

Dla obu próbek dokonano również dokładnej analizy w postaci podziału przestrzeni porowej na sieć porów połączonych (rysunek 3) oraz niepołączonych, czyli odizolowanych (rysunek 4). Na podstawie uzyskanych obrazów widać, że obie próbki składają się głównie z jednej sieci porów połączonych. W przypadku próbki nr 2 wykonano również analizę szkieletu sieci porów połączonych, czyli wyodrębniono pojedyncze gałęzie sieci oraz ich połączenia.

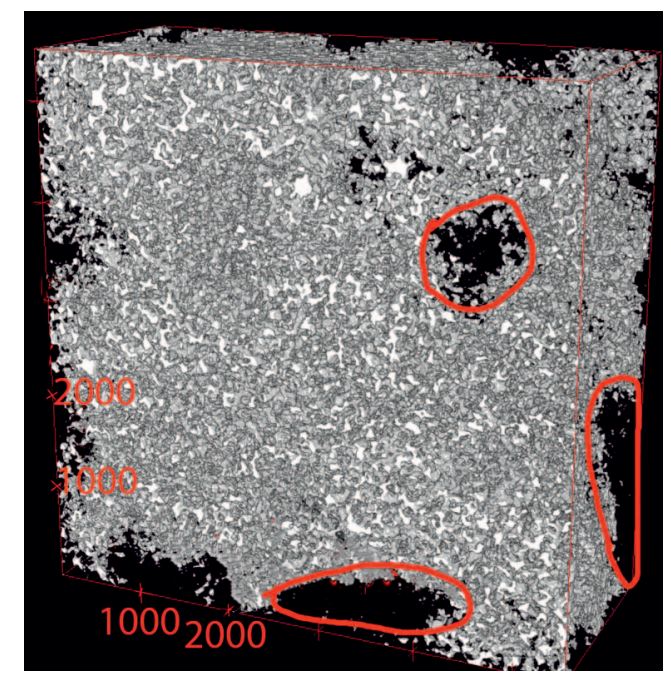

Rys. 2. Wizualizacja przestrzeni porowej próbki nr 1 z zaznaczonymi dużymi ziarnami mineralnymi

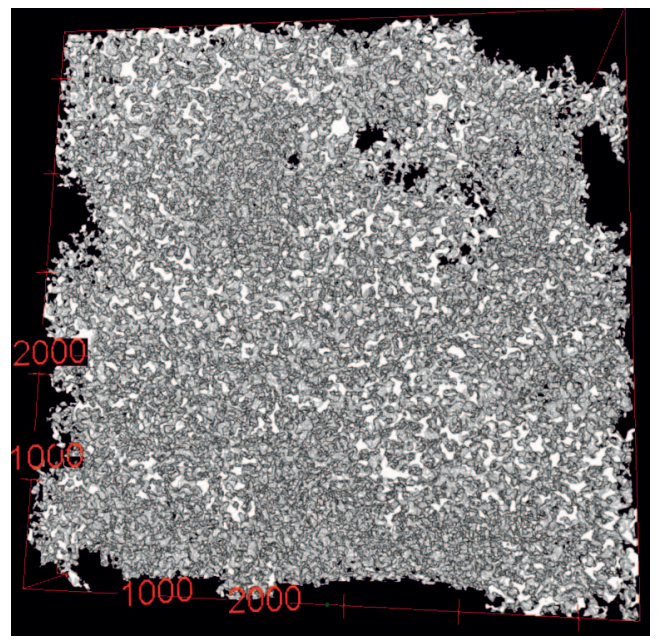

Rys. 3. Sieć porów połączonych, próbka nr 1

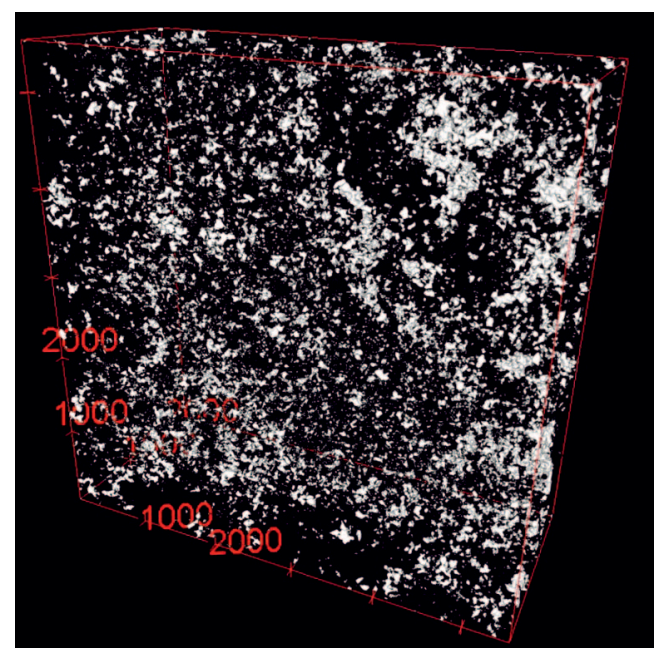

Rys. 4. Sieć porów odizolowanych, próbka nr 1

\section{Interpretacja ilościowa - charakterystyka 2D porów}

Pierwszym etapem interpretacji ilościowej było policzenie liczby białych i czarnych wokseli za pomocą modułu „Voxel counter” w ImageJ [12]. Pory odpowiadają białym wokselom, a szkielet - czarnym. Porowatość całkowita jest stosunkiem wokseli białych do sumy czarnych i białych wokseli. Uzyskane wartości porowatości wraz z porównaniem z wartościami porowatości zmierzonymi innymi metodami laboratoryjnymi znajdują się w tablicy 1 . Porowatość całkowita była zbliżona do obliczonej z wykorzystaniem innych metod labo-

Tablica 1. Porównanie uzyskanych porowatości całkowitych $\mathrm{z}$ innymi metodami laboratoryjnymi

\begin{tabular}{|c|c|c|c|}
\cline { 2 - 4 } \multicolumn{1}{c|}{} & Micro-CT & $\begin{array}{c}\text { Piknometria } \\
\text { helowa }\end{array}$ & Spektrometria NMR \\
\cline { 2 - 4 } & \multicolumn{3}{|c|}{$[\%]$} \\
\hline Próbka 1 & 13,72 & 11,7 & 14,7 \\
\hline Próbka 2 & 13,68 & 13,3 & 12,8 \\
\hline
\end{tabular}

ratoryjnych. W przypadku próbki nr 1 różnica wyniosła 2\% w stosunku do metody piknometrii helowej i 1\% w stosunku do metody spektrometrii magnetycznego rezonansu jądrowego (NMR). Dla próbki nr 2 różnice wyniosły $0,4 \%$ i 0,9\%.

Następnie posłużono się modułem „Analyse particles” (ImageJ) w trybie analizy 2D. Moduł ten oblicza liczbę jasnych i ciemnych wokseli w każdym przekroju, odpowiada to za krok przestrzenny $z$. Uzyskane wyniki zamieszczono na rysunku 1.

Próbka nr 1 cechowała się na początku wysoką porowatością całkowitą, wynoszącą 17\%, która następnie spadła i oscylowała w okolicach 13\%. Natomiast próbka nr 2 charakteryzowała się mniej więcej stałą porowatością całkowitą w całym zakresie przekrojów 2D, oscylującą w przedziale $13 \div 15 \%$. Próbka nr 1 wykazała heterogeniczność w wykształceniu przestrzeni porowej.

Policzono też liczbę porów przypadającą na każdy przekrój (rysunek 6) oraz średni rozmiar porów na przekrój (rysunek 7). 


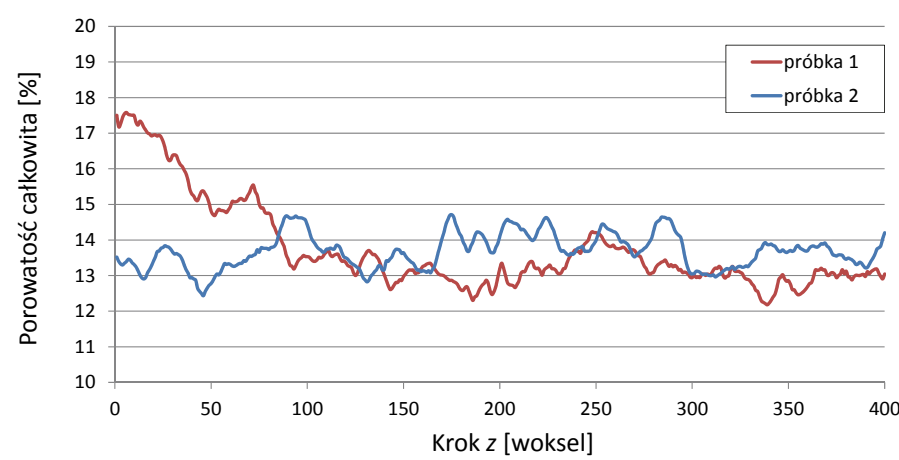

Rys. 5. Porowatość całkowita w zależności od kroku z

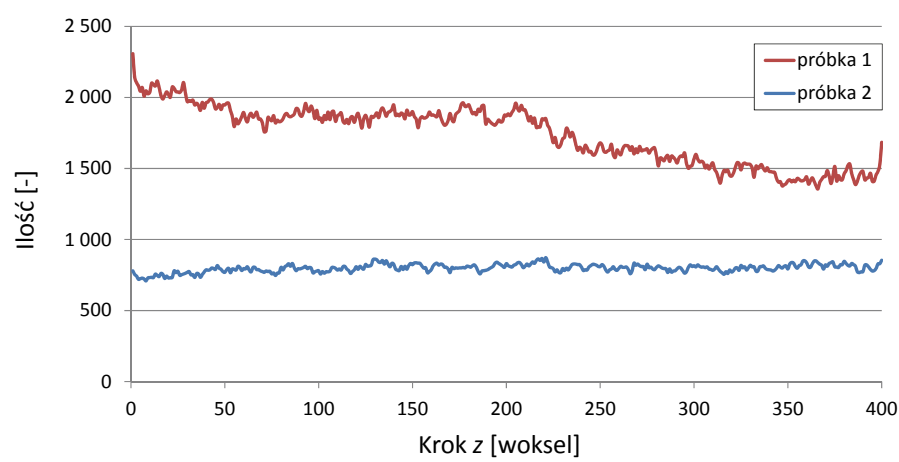

Rys. 6. Liczba porów w zależności od kroku z

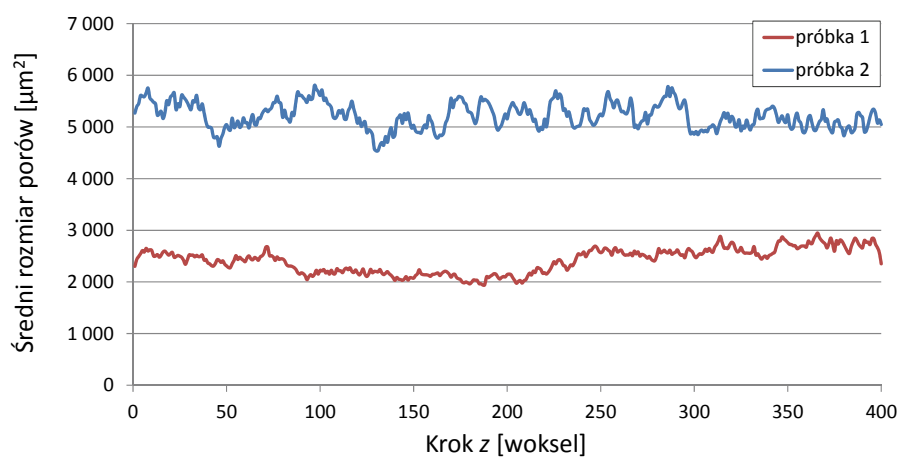

Rys. 7. Średni rozmiar porów w zależności od kroku z

Na podstawie uzyskanych wyników widać, że próbka nr 1 cechuje się większą liczbą porów (między 1356 a 2308) niż próbka nr 2 (między 709 a 872). Porowatości całkowite obu próbek były zbliżone, jednak średni rozmiar porów próbki nr 2 był większy i oscylował w przedziale $4536 \div 5802 \mu \mathrm{m}^{2}$, a w przypadku próbki nr 1 - w przedziale $1939 \div 2946 \mu \mathrm{m}^{2}$.

Dokonano podziału przestrzeni porowej na klasy powierzchni, obliczono liczbę obiektów (porów) przyporządkowanych do danej klasy oraz ich procentowy udział w budowaniu całej przestrzeni porowej. Na podstawie rysunku 8 widać, że dla próbki nr 1 zliczono najwięcej porów o powierzchni między $100 \mu \mathrm{m}^{2}$ a $1000 \mu \mathrm{m}^{2}$. Na podstawie rysunku 9 zaobserwowano największy udział w budowie przestrzeni porowej porów o powierzchniach między $1000 \mu \mathrm{m}^{2}$ a $100000 \mu \mathrm{m}^{2}$.

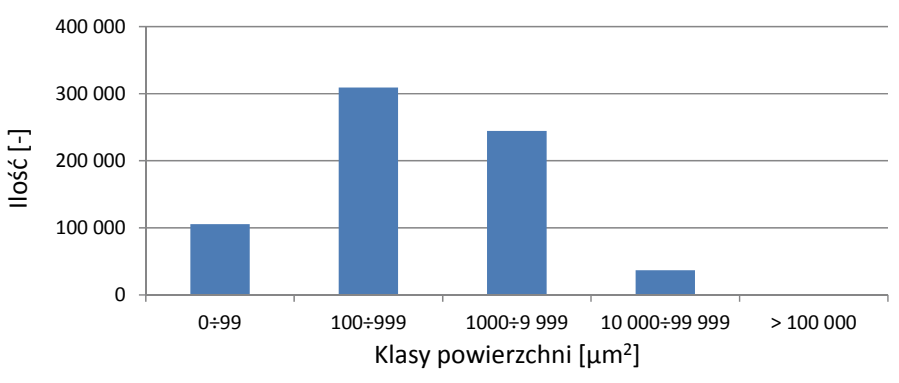

Rys. 8. Liczba porów w zależności od klasy powierzchni - próbka nr 1

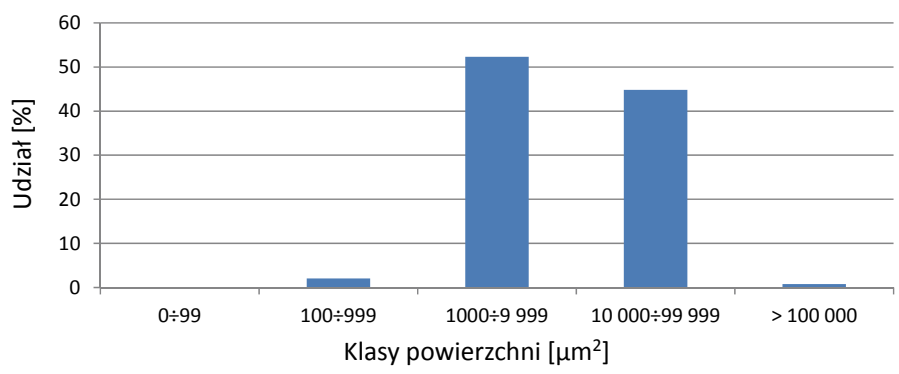

Rys. 9. Udział porów w zależności od klasy powierzchni - próbka nr 1

W przypadku próbki nr 2 najwięcej porów charakteryzowało się powierzchnią między $1000 \mu \mathrm{m}^{2}$ a $10000 \mu \mathrm{m}^{2}$. Mimo to dominujący udział $\mathrm{w}$ budowie przestrzeni porowej miały pory o powierzchni między $10000 \mu \mathrm{m}^{2}$ a $100000 \mu \mathrm{m}^{2}$ (rysunki 10 i 11). Przestrzeń porowa próbki nr 2 jest zbudowana z porów o większej powierzchni niż w próbce nr 1 .

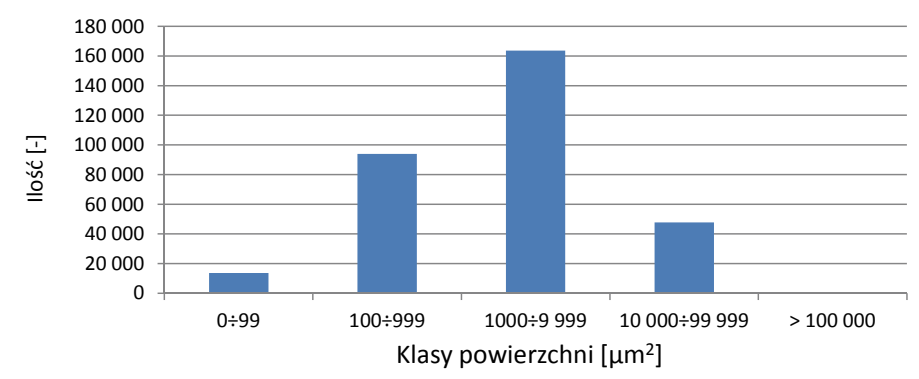

Rys. 10. Liczba porów w zależności od klasy powierzchni - próbka nr 2

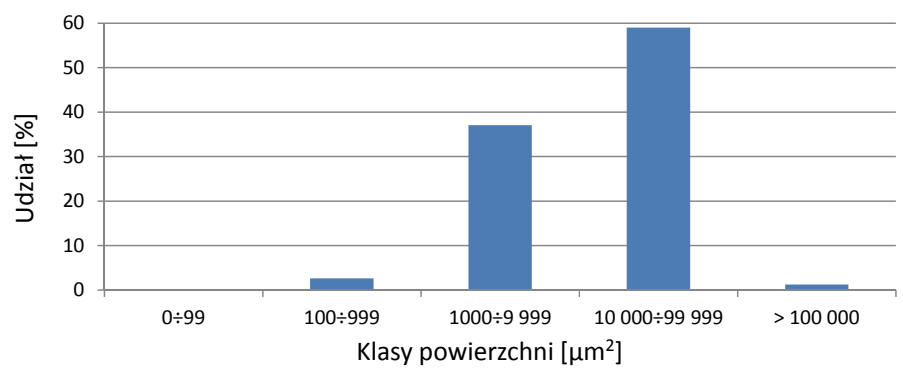

Rys. 11. Udział porów w zależności od klasy powierzchni - próbka nr 2 


\section{Interpretacja ilościowa - charakterystyka 3D porów}

Analizę 3D przestrzeni porowej rozpoczęto od podzielenia przestrzeni porowej na sieć porów połączonych i na pory odizolowane. Dokonano tego, używając modułu „BoneJ - Particle analyser" (wtyczka do ImageJ) [10]. Ilościowa analiza porów należących do sieci porów połączonych i odseparowanych dostarczyła następujących, porównywalnych wartości:

- dla próbki nr 1 objętość porów połączonych wyniosła $9,210 \mathrm{~mm}^{3}$, a suma objętości porów odseparowanych: $0,413 \mathrm{~mm}^{3}$,

- dla próbki nr 2 objętość porów połączonych wyniosła $9,201 \mathrm{~mm}^{3}$, a suma objętości porów odseparowanych: $0,421 \mathrm{~mm}^{3}$,

- dla próbki nr 1 stosunek porów odseparowanych do połączonych wynosił 4,5\%,

- dla próbki nr 2 stosunek porów odseparowanych do połączonych wynosił 4,6\%.

W przypadku obu próbek porowatość całkowita policzona $\mathrm{z}$ danych 3D była równa 13,7\% i zgadzała się z dokładnością $0,05 \%$ z porowatością całkowitą wyliczoną z danych $2 \mathrm{D}$. Porowatość efektywna, za którą przyjęto objętość porów połączonych, wyniosła dla obu próbek 13,1\%.

Policzono również charakterystykę Eulera. Dla próbki nr 1 otrzymano charakterystykę Eulera wynoszącą -44 853, a dla próbki nr 2: -7625 . Obie wartości są silnie ujemne. Próbka nr 1 charakteryzuje się lepszą jakością połączeń struktury porowej niż próbka nr 2, gdyż jej charakterystyka Eulera jest o wiele mniejsza. Liczba połączeń pomiędzy porami jest o wiele większa w próbce nr 1, stąd różnica w wartości charakterystyki Eulera.

Analizę sieci porów połączonych wykonano przy użyciu modułów „Skeletonise” i „Analyse skeleton” w ImageJ. Wynikiem polecenia ,Skeletonise” jest stworzenie struktury o szerokości jednego woksela, która odwzorowuje układ geometryczny i topologię sieci porów połączonych. Moc obliczeniowa komputera nie wystarczyła do wy-

Tablica 2. Średnia krętość w zależności od długości gałęzi w próbce nr 2

\begin{tabular}{|l|c|c|c|c|c|c|}
\hline Długość gałęzi $[\mu \mathrm{m}]$ & $0 \div 99$ & $100 \div 199$ & $200 \div 299$ & $300 \div 399$ & $400 \div 499$ & $>500$ \\
\hline Krętość $[-]$ & 1,18 & 1,28 & 1,48 & 1,74 & 1,90 & 2,24 \\
\hline
\end{tabular}

konania analiz dla próbki nr 1 . Próbka nr 1 charakteryzowała się występowaniem większej liczby obiektów budujących przestrzeń porową. Komputer, na którym przeprowadzano obliczenia, posiadał 12 GB pamięci RAM, która po około 30 sekundach pracy od uruchomienia procedury dla próbki nr 1 uległa zapełnieniu. W przypadku próbki nr 2 procedura zaalokowała około $10 \mathrm{~GB}$ pamięci RAM i potrzebowała około 5 minut na wykonanie obliczeń. Mimo że dla próbki nr 1 procedura nie wyświetliła komunikatu o błędzie, to jednak po 6 godzinach zawieszonej pracy komputera zdecydowano się na jej przerwanie.

Dla próbki nr 2 uzyskano sieć o sumarycznej długości $5141 \mathrm{~mm}$ posiadającą 26899 skrzyżowań, które definiujemy jako woksele połączone $z$ więcej niż dwoma sąsiadującymi wokselami (więcej niż dwóch sąsiadów). Sieć ta ma również 54806 gałęzi, które są połączeniami między skrzyżowaniami i/lub wokselami mającymi tylko jednego sąsiada. Dokonano również podziału gałęzi na klasy długości (rysunek 12). Na tej podstawie można zaobserwować, że sieć składa się głównie z krótkich odgałęzień o długościach poniżej $200 \mu \mathrm{m}$.

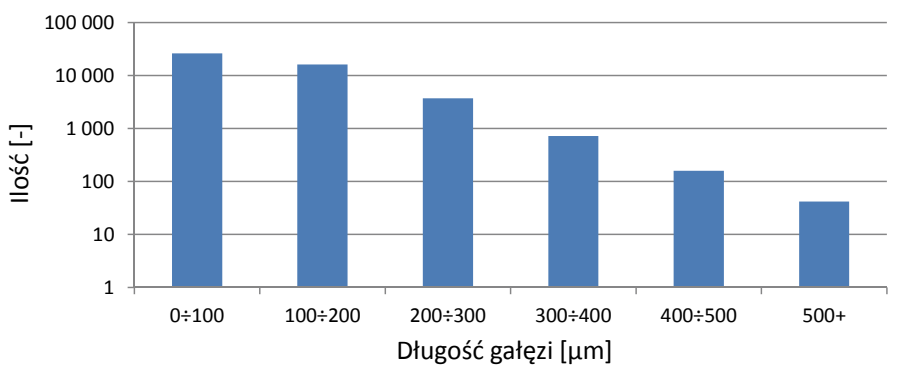

Rys. 12. Liczba gałęzi w zależności od klasy długości - próbka nr 2

Istotnym parametrem poddanym analizie była również krętość kanałów porowych, która definiowana jest jako dłuległość euklidesową między nimi. Przyjmuje ona wartość 1 dla linii prostej i rośnie w przypadku bardziej skomplikowanych kształtów.

W celu policzenia krętości wyodrębniono z sieci porowej najdłuższą ze ścieżek. Jest to suma gałęzi, która unika zapętleń i daje największą długość. W przypadku próbki nr 2 wyodrębniono fragment o wymiarach 1,3 × 1,3 3 2,3 $\mathrm{mm}$, a następnie policzono dla niego najdłuższą ścieżkę (przedstawiona na rysunku 13). Uzyskano dla niej krętość wynoszącą 2,17, co obrazuje umiarkowanie skomplikowany jej charakter. gość ścieżki między dwoma punktami podzielona przez od- 
Dla całej próbki nr 2 policzono krętość w zależności od klasy długości poszczególnych jej gałęzi. Otrzymane wyniki zamieszczono w tablicy 2. Wartość krętości rośnie wraz ze wzrostem długości gałęzi branej do analizy.

Dla sieci porów odizolowanych dokonano jej podziału na klasy objętości, następnie policzono liczbę elementów

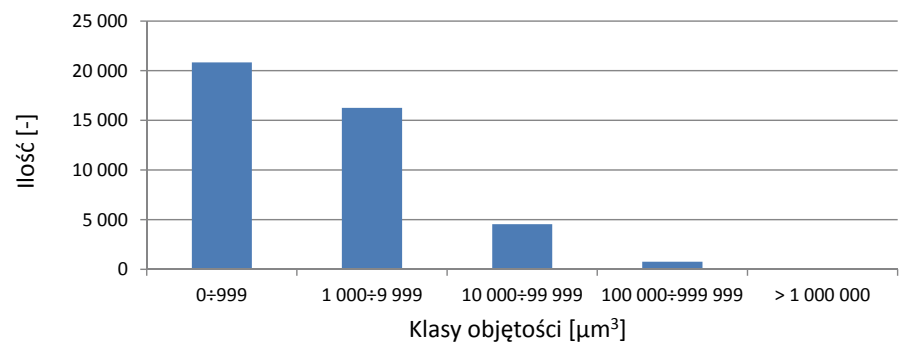

Rys. 14. Liczba porów odizolowanych w zależności od klasy objętości - próbka nr 1

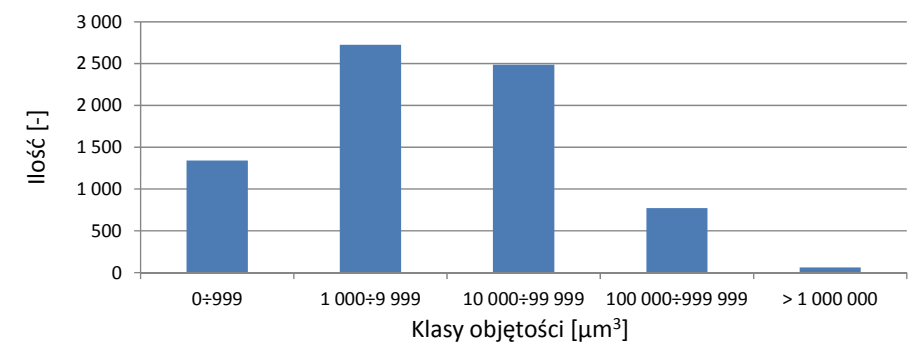

Rys. 16. Liczba porów odizolowanych w zależności od klasy objętości - próbka nr 2 w danej klasie oraz jej procentowy udział. Uzyskane wyniki przedstawiają rysunki 14-17. Podobnie jak w przypadku analizy 2D próbka nr 1 posiadała więcej elementów o mniejszych objętościach. W obu przypadkach największy udział procentowy miały pory o objętościach między $100000 \mu \mathrm{m}^{3}$ a $1000000 \mu \mathrm{m}^{3}$.

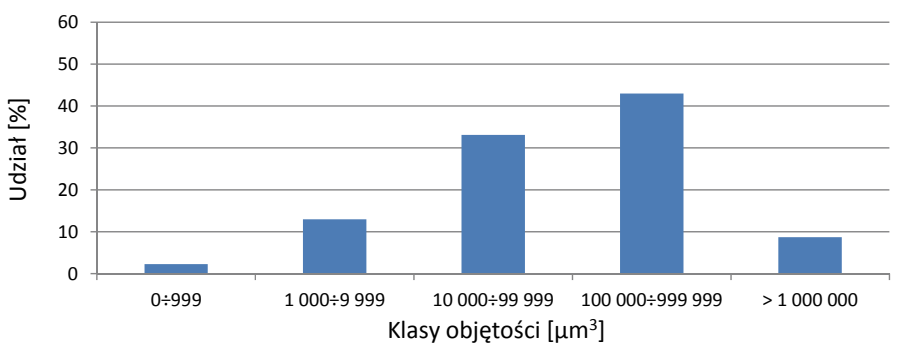

Rys. 15. Udział porów odizolowanych w zależności od klasy objętości - próbka nr 1

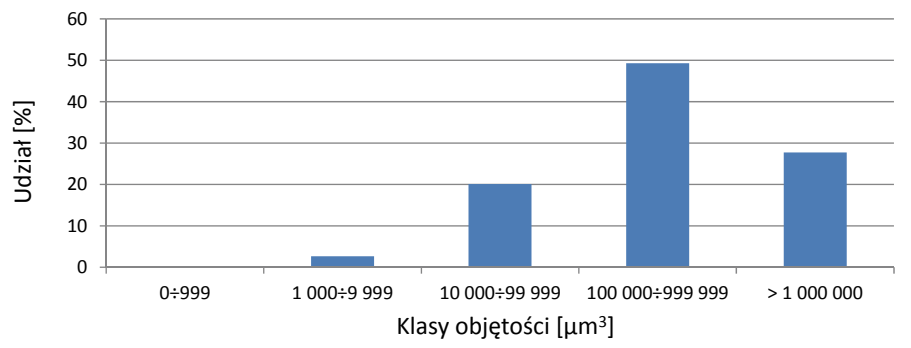

Rys. 17. Udział porów odizolowanych w zależności od klasy objętości - próbka nr 2

\section{Wnioski}

Rentgenowska tomografia komputerowa okazała się użytecznym narzędziem do badania przestrzeni porowej skał $[5,6$, $13,14]$ i dostarcza możliwości na polu obrazowania badanych próbek w 2D i 3D. Dzięki temu już na etapie interpretacji jakościowej można wysuwać wnioski, które następnie znajdują odzwierciedlenie w interpretacji ilościowej:

- obie próbki składały się głównie z połączonej sieci porów,

- próbka nr 1 wykazała heterogeniczność w wykształceniu przestrzeni porowej, cechowała się większą liczbą porów, lepszą jakością połączeń struktury porowej (charakterystyka Eulera) oraz posiadała więcej porów o mniejszych objętościach,

- próbka nr 2 posiadała pory o większych rozmiarach, przestrzeń porowa była zbudowana z porów o większej po- wierzchni, obliczona krętość największego wyodrębnionego kanału porowego wynosiła 2,17.

W kwestii interpretacji ilościowej możliwe było analizowanie heterogeniczności przestrzeni porowej w dowolnie zadanych kierunkach. Zaobserwowano, że próbka nr 1 ma zmienny charakter porowatości całkowitej w porównaniu do próbki nr 2. Możliwy był również podział próbki na sieć porów połączonych i odizolowanych, co pozwoliło na wyliczenie porowatości efektywnej. Dokonano także obliczeń bardziej zaawansowanych parametrów, takich jak charakterystyka Eulera oraz krętość kanałów porowych.

W zestawieniu z innymi metodami laboratoryjnymi uzyskane wyniki porowatości całkowitej nie wykazywały dużych rozbieżności.

\section{Podziękowania}

Praca została wykonana dzięki realizacji programu Lider VI, projekt pt. Nowatorska metodyka interpretacji niekonwencjonalnych złóż ropy i gazu z wykorzystaniem wyników rentgenowskiej tomografii komputerowej (umowa LIDER/319/L-6/14/NCBR/2015), finansowanego przez Narodowe Centrum Badań i Rozwoju. Autorzy dziękują Ministerstwu Środowiska za udostępnienie danych geologicznych i petrofizycznych. Autorzy dziękują dr. inż. Markowi Dohnalikowi (INiG - PIB w Krakowie) za dane tomograficzne oraz recenzentom za cenne uwagi. 


\section{NAFTA-GAZ}

Prosimy cytować jako: Nafta-Gaz 2018, nr 7, s. 487-494, DOI: 10.18668/NG.2018.07.01

Artykuł nadesłano do Redakcji 7.02.2018 r. Zatwierdzono do druku 22.05.2018 r.

\section{Literatura}

[1] Bielecki J., Jarzyna J., Bożek S., Lekki J., Stachura Z., Kwiatek W.M.: Computed microtomography and numerical study of porous rock samples. Radiation Physics and Chemistry 2013, vol. 93, s. 59-66.

[2] Cnudde V., Boone M.: High-resolution X-ray computed tomography in geosciences: A review of the current technology and applications. Earth-Science Reviews 2013, vol. 123, s. 1-17.

[3] Dohnalik M.: Zwiększenie możliwości wyznaczania parametrów zbiornikowych skat z wykorzystaniem rentgenowskiej mikrotomografii komputerowej. Rozprawa doktorska, Biblioteka WGGiOŚ AGH, Kraków 2013, s. 26-37.

[4] Jarzyna J., Krakowska P., Puskarczyk E., Wawrzyniak-Guz K., Bielecki J., Tkocz K., Tarasiuk J., Wroński S., Dohnalik M.: $X$-ray computed microtomography - a useful tool for petrophysical properties determination. Computational Geosciences 2016, vol. 20, nr 5, s. 1155-1167.

[5] Kaczmarek Ł., Kozłowska A., Maksimczuk M., Wejrzanowski T.: The use of X-ray computed microtomography for graptolite detection in rock based on core internal structure visualization. Acta Geologica Polonica 2017, vol. 67, nr 2, s. 299-306.

[6] Krakowska P., Dohnalik M., Jarzyna J., Wawrzyniak-Guz K.: Computed X-ray microtomography as the useful tool in petrophysics: A case study of tight carbonates Modryn formation from Poland. Journal of Natural Gas Science and Engineering 2016, vol. 31, s. 67-75.
[7] Manecki A., Muszyński M. (red.): Przewodnik do petrografii. Uczelniane Wydawnictwo Naukowo-Techniczne AGH, Kraków 2008, s. 216-236.

[8] Plewa M., Plewa S.: Petrofizyka. Wydawnictwa Geologiczne, Warszawa 1992, s. 32-41.

[9] Stock S.R.: MicroComputed Tomography. Methodology and Application. CRS Press, Taylor and Francis Group, Boca Raton, London, New York 2008, s. 1-336.

[10] Strona główna dystrybucji BoneJ do programu ImageJ, http:// bonej.org/ (dostęp: styczeń 2018).

[11] Strona główna wtyczki 3D Viewer do programu ImageJ, https:// imagej.nih.gov/ij/plugins/3d-viewer/ (dostęp: styczeń 2018).

[12] Strona główna wtyczki Voxel Counter do programu ImageJ, https://imagej.nih.gov/ij/plugins/voxel-counter.html (dostęp: styczeń 2018).

[13] Zalewska J., Dohnalik M., Kaczmarczyk J., Poszytek A., Sikora G., Cebulski D., Masłowski M., Biały E.: Rentgenowska mikrotomografia komputerowa w badaniu skat weglanowych. Prace Naukowe Instytutu Nafty i Gazu 2010, nr 171, s. 1-264.

[14] Zalewska J., Poszytek A., Dohnalik M.: Wizualizacja i analiza przestrzeni porowej piaskowców czerwonego spagowca metoda rentgenowskiej mikrotomografii komputerowej (micro-CT). Prace Instytutu Nafty i Gazu 2009, nr 161, s. 1-83.
Inż. Piotr GOŁDA

Student II stopnia Geofizyki na Wydziale Geologii, Geofizyki i Ochrony Środowiska

Akademia Górniczo-Hutnicza im. St. Staszica

w Krakowie

al. Mickiewicza 30, 30-059 Kraków

E-mail:piotrgolda6@gmail.com

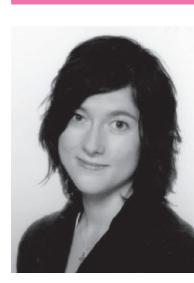

Dr inż. Paulina KRAKOWSKA

Adiunkt na Wydziale Geologii, Geofizyki

i Ochrony Środowiska

Akademia Górniczo-Hutnicza im. St. Staszica

w Krakowie

al. Mickiewicza 30, 30-059 Kraków

E-mail.krakow@agh.edu.pl 